\title{
Factors Affecting the Content of Ergosterol and Zearalenone in Selected Grass Species at the End of the Growing Season
}

\author{
Jiří Skládanka ${ }^{1}$, Vlastimil Dohnal ${ }^{2}$, Petr Doležal ${ }^{1}$, Alena Ježková ${ }^{2}$ Ladislav Zeman ${ }^{1}$ \\ ${ }^{1}$ Department of Animal Nutrition and Forage Production, ${ }^{2}$ Department of Food Technology, Faculty of \\ Agronomy, Mendel University of Agriculture and Forestry Brno, Czech Republic
}

Received July 2, 2008

Accepted November 12, 2008

\begin{abstract}
The objective of the study was to assess the safety of forage prepared from selected grass species by means of the analysis of ergosterol and zearalenone. Graminaceous plants studied at the end of their growing season were Festulolium, Dactylis glomerata and Arrhenatherum elatius. Other indicators assessed were the content of ergosterol and zearalenone during the autumn and the intensity of grassland use in the summer season as related to the studied contents of metabolites. Grasslands were harvested either in October, November or December. The secondary metabolites were analyzed by means of high performance liquid chromatography. At the end of the growing season, the ergosterol content was the lowest in the Festulolium forage (110.04 $\mathrm{mg} \cdot \mathrm{kg}^{-1}$ ), the highest contents were observed in the Dactylis glomerata and Arrhenatherum elatius forages $\left(145.73 \mathrm{mg} \cdot \mathrm{kg}^{-1}\right.$ and $139.55 \mathrm{mg} \cdot \mathrm{kg}^{-1}$, respectively). The safety of Festulolium was also corroborated by the low zearalenone content $\left(0.357 \mathrm{mg} \cdot \mathrm{kg}^{-1}\right)$. On the other hand, the high ergosterol content in Arrhenatherum elatius was combined with a high content of zearalenone $\left(1.554 \mathrm{mg} \cdot \mathrm{kg}^{-1}\right)$. Although Dactylis glomerata exhibited an ergosterol content comparable with that of Arrhenatherum elatius forage, its zearalenone content was comparable to the Festulolium forage. Among the three species under study we found a significant difference $(P<0.01)$ in the ergosterol and zearalenone contents. Changes in the ergosterol and zearalenone contents were also apparent from October to December. The highest $(P<0.01)$ content of ergosterol was found in December $\left(254.26 \mathrm{mg} \cdot \mathrm{kg}^{-1}\right)$. The higher $(P<0.01)$ zearalenone content in this month $(1.588$ $\left.\mathrm{mg} \cdot \mathrm{kg}^{-1}\right)$ was caused by the Arrhenatherum elatius forage. Moreover, the contents of ergosterol and zearalenone were affected $(P<0.01)$ also by the number of cuts in summer. The higher ergosterol content indicated a higher forage infestation by fungi and the inherent risk of the occurrence of mycotoxins. However, the high ergosterol content not always correlated with the high content of zearalenone. When cattle is grazing in winter, a higher occurrence of mycotoxins in the feed may be expected and the related damage to animal metabolism may increase the number of diseased animals with consequent impact on animal production, performance and health and animal husbandry economics.
\end{abstract}

Forage, Festulolium, Dactylis glomerata, Arrhenatherum elatius, winter grazing, mycotoxins, HPLC

Microorganisms in the phyllosphere of grasses are markedly influenced by changes in grassland management, particularly by transition from the intensive management to extensification due to reduced cutting frequencies and fewer fertilizer applications (Behrendt et al. 1997). In late autumn, the vegetation of pasture plants gradually decreases and weather conditions stimulate the development of microscopic fungi (Giesler et al. 1996) which, in consequence, may lead to the formation of mycotoxins (Opitz von Boberfeld et al. 2006; Behrendt et al. 2004). Besides population density, the formation of the toxic mycotoxins additionally depends on several biotic and abiotic factors (De Nijs et al. 1996; Engels and Krämer 1996). These metabolites can cause economic losses in animal production and decrease meat quality (Opitz von Boberfeld 1996). The issue of moulds is very topical, namely in connexion with forages from grass stands used at the end of the growing season. There are considerable differences amongst the species. Mouldresistant species include Festuca arundinacea and its hybrids (Opitz von Boberfeld

Phone: +420545133079

Fax: +420545133075

Email: sklady@mendelu.cz

http://www.vfu.cz/acta-vet/actavet.htm 
and Banzhaf 2006). The use of Dactylis glomerata at the end of the growing season is mentioned by Prigge et al. (1999).

Ergosterol ranks amongst the main sterols produced by lower and higher fungi. Its occurrence in other organisms is very limited, negligible concentrations of ergosterol in dry matter (DM) were only detected in some bacteria and yeasts. Due to this specific occurrence, it is possible in practice to associate the occurrence of this sterol with the presence of moulds in the analyzed sample (Marín et al. 2007). Zearalenone is one of mycotoxins produced by the Fusarium genus. It can be detected in the forage of grass stands. It exhibits high oestrogenic activity. Apart from the direct impact on ruminants, the contaminated forage affects rumen microorganisms, too (Wolf 2002).

The goal of this study was to assess by means of the contents of ergosterol and zearalenone the safety of Festulolium, Dactylis glomerata and Arrhenatherum elatius forages at the end of the growing season. Variables assessed were changes in the content of ergosterol and zearalenone during the autumn, and the intensity of grassland use in summer on the content of these metabolites.

\section{Materials and Methods}

Site description

The small-plot experiment was established in 2004 in the Bohemian-Moravian Upland at an altitude of $560 \mathrm{~m}$ above see level. In 1970 - 2000, mean annual precipitation was $617 \mathrm{~mm}$ and mean annual temperature amounted to $6.9{ }^{\circ} \mathrm{C}$. Three years that rather differed in weather were monitored. In 2005 , the total annual precipitation amount was $660 \mathrm{~mm}$ and the average temperature reached $6.9^{\circ} \mathrm{C}$. In the monitored months of October, November and December, the precipitation reached $2.8 \mathrm{~mm}, 25.6 \mathrm{~mm}$ and $68.8 \mathrm{~mm}$ and the average daily temperature was $7.81{ }^{\circ} \mathrm{C}, 0.72{ }^{\circ} \mathrm{C}$ and $-1.97{ }^{\circ} \mathrm{C}$, respectively. In 2006 , the total annual precipitation was $727.5 \mathrm{~mm}$ and the average temperature reached $7.0^{\circ} \mathrm{C}$. In the monitored months of October, November and December, the precipitation amounted to $25.7 \mathrm{~mm}, 76.6 \mathrm{~mm}$ and $22.2 \mathrm{~mm}$ an the average daily temperature was $7.75{ }^{\circ} \mathrm{C}, 4.50{ }^{\circ} \mathrm{C}$ and $2.57^{\circ} \mathrm{C}$, respectively. In 2007, the total annual precipitation was $705.3 \mathrm{~mm}$ and the average temperature reached $8.3^{\circ} \mathrm{C}$. In the monitored months of October, November and December, the precipitation amounted to $23.1 \mathrm{~mm}, 106.5 \mathrm{~mm}$ and $27.0 \mathrm{~mm}$ an the average daily temperature was $6.0^{\circ} \mathrm{C}, 0.20^{\circ} \mathrm{C}$ and $-2.43{ }^{\circ} \mathrm{C}$, respectively.

Experimental factors

The first experimental factor was the grass species (S). The species under study were Festulolium cv. Felina, Dactylis glomerata cv. Vega, Arrhenatherum elatius cv. Median. The second experimental factor was the intensity of use of grassland in summer (C), when the sward was used as a single-cut stand (1C) only in June or as a double-cut stand $(2 \mathrm{C})$ in June and at the end of July. The third experimental factor was the time of harvest in the autumn (A). The sward was harvested either in October, November or December. The time of the autumn harvest corresponded to the time of sampling for the chemical analyses. The experiment was repeated in three subsequent years 2005, 2006 and 2007.

\section{Measurements}

The monitored characteristics were zearalenone content and ergosterol content. Samples dried at $60{ }^{\circ} \mathrm{C}$ and homogenised to a particle size of $1 \mathrm{~mm}$ were analysed. The number of 162 samples was analyzed. Zearalenone and ergosterol were determined using high performance liquid chromatography (HPLC) Model HP1100. The chromatograph (Agilent Technologies, Palo Alto, U.S.A.) consisted of vacuum degassing unit Model G1322A, quaternary mobile phase pump Model G1311A, automated sample injector Model G1313A, UV-VIS variable wavelength detector Model G1314A, fluorescence detector Model G1321A and mass detector Model G1946VL.

\section{Ergosterol determination}

The determination of ergosterol was performed on reverse phase chromatographic column Zorbax SB-C18 sized $4.6 \times 30 \mathrm{~mm}$ with the particles size of $1.8 \mu \mathrm{m}$ (Agilent Technologies, U.S.A.). The separation was carried out at a laboratory temperature using isocratic elution - mobile phase with a composition of methanol/water $(97.5 / 2.5, \mathrm{v} / \mathrm{v})$ at a volumetric velocity of $0.6 \mathrm{ml} / \mathrm{min}$. Ergosterol was detected with UV detector at $282 \mathrm{~nm}$ (Dohnal et al. 2007).

\section{Zearalenone determination}

The zearalenone determination was performed according to original methodology of Romer Labs (Austria). An amount of $12.5 \mathrm{~g}$ of the sample were placed into an Erlenmeyer flask and the $150 \mathrm{ml}$ of $\mathrm{ACN} / \mathrm{H}_{2} \mathrm{O}(84 / 16$, v/v) mixture were added. The sample was mixed by UltraTurrax (Heidolph DIAX 900, Germany) for 3 min and centrifuged at $755 \mathrm{~g}$ (Universal 32R, Hettich, Germany) for $5 \mathrm{~min}$. Subsequently, $8 \mathrm{ml}$ of supernatant were taken, acidified with $80 \mu \mathrm{l}$ of acetic acid and pre-cleaned on the MycoSep 226 AflaZon+ column (Romer Labs, Austria). An amount of $4 \mathrm{ml}$ of the pre-cleaned sample were evaporated at $40{ }^{\circ} \mathrm{C}$ by a mild nitrogen flow to dryness and redissolved in $200 \mu$ l of the mobile phase. The chromatographic separation was performed on Hypersil ODS column 
$(100 \times 2.1 \mathrm{~mm}$, particle size $3 \mu \mathrm{m})$ made by Agilent Technologies (U.S.A.). The mobile phase composition was constant in time and corresponded to a water/methanol/ACN ratio of 5/4/1 with the flow rate $0.45 \mathrm{ml} / \mathrm{min}$ at a temperature of $45^{\circ} \mathrm{C}$. The detection took place on a UV detector at a wavelength of $236 \mathrm{~nm}$.

\section{Statistical evaluation}

The results were analysed using the multi-factor analysis of variance and by subsequent verification based on the Tukey Test.

\section{Results}

The content of secondary metabolites in forage from grass stands harvested in the autumn depends on the grass species, on the intensity of use in summer and on the time of harvest in the autumn (Table 1). The Festulolium forage contained the least ergosterol amount compared to the Dactylis glomerata forage and the Arrhenatherum elatius forage (see Table 2). Grass species had a significant influence $(P<0.01)$ on the ergosterol content: it

Table 1. Effects of the species, intensity of grassland use in summer and period of autumn use on the contents of ergosterol and zearalenone

\begin{tabular}{|c|c|c|c|c|c|c|c|}
\hline \multirow[b]{2}{*}{ Factor } & \multirow{2}{*}{$\begin{array}{c}\text { Degrees } \\
\text { of } \\
\text { freedom }\end{array}$} & \multicolumn{3}{|c|}{ Ergosterol } & \multicolumn{3}{|c|}{ Zearalenone } \\
\hline & & $\begin{array}{c}\text { Mean } \\
\text { square }\end{array}$ & F-value & $p$ & $\begin{array}{c}\text { Mean } \\
\text { square }\end{array}$ & F-value & $p$ \\
\hline $\mathrm{S}$ & 2 & 19646 & 6.5313 & 0.001927 & 27.28718 & 7.09788 & 0.001148 \\
\hline $\mathrm{C}$ & 1 & 21040 & 6.9950 & 0.009081 & 7.42147 & 1.93046 & 0.166853 \\
\hline $\mathrm{A}$ & 2 & 616585 & 204.9878 & 0.000000 & 30.05098 & 7.81680 & 0.000599 \\
\hline $\mathrm{S} \times \mathrm{C}$ & 2 & 19506 & 6.4850 & 0.002011 & 8.73286 & 2.27157 & 0.106834 \\
\hline $\mathrm{S} \times \mathrm{A}$ & 4 & 16271 & 5.4095 & 0.000436 & 13.94728 & 3.62794 & 0.007551 \\
\hline $\mathrm{C} \times \mathrm{A}$ & 2 & 10625 & 3.5324 & 0.031795 & 0.73922 & 0.19228 & 0.825284 \\
\hline $\mathrm{S} \times \mathrm{C} \times \mathrm{A}$ & 4 & 4403 & 1.4639 & 0.216261 & 0.57219 & 0.14884 & 0.963260 \\
\hline Error & 144 & 3008 & & & 3.84441 & & \\
\hline
\end{tabular}

$\mathrm{S}=$ grass species, $\mathrm{C}=$ intensity of use in summer, $\mathrm{A}=$ harvest in autumn

Table 2. The contents of ergosterol $\left(\mathrm{mg} \cdot \mathrm{kg}^{-1}\right)$ and zearalenone $\left(\mathrm{mg} \cdot \mathrm{kg}^{-1}\right)$

\begin{tabular}{|c|c|c|c|}
\hline Factor & $\mathrm{N}$ & $\begin{array}{c}\text { Ergosterol } \\
\mathrm{mg} \cdot \mathrm{kg}^{-1}\end{array}$ & $\begin{array}{c}\text { Zearalenone } \\
\mathrm{mg} \cdot \mathrm{kg}^{-1}\end{array}$ \\
\hline \multicolumn{4}{|l|}{ Grass species } \\
\hline Festulolium & 54 & $110.04 \pm 12.26^{\mathrm{a}}$ & $0.357 \pm 0.142^{\mathrm{a}}$ \\
\hline Dactylis glomerata & 54 & $145.73 \pm 15.81^{b}$ & $0.291 \pm 0.098^{\mathrm{a}}$ \\
\hline Arrhenatherum elatius & 54 & $139.55 \pm 15.47^{b}$ & $1.554 \pm 0.463^{b}$ \\
\hline \multicolumn{4}{|c|}{ Intensity of use in summer } \\
\hline $1 \mathrm{C}$ & 81 & $143.17 \pm 10.84^{\mathrm{a}}$ & $0.520 \pm 0.194^{\mathrm{a}}$ \\
\hline $2 \mathrm{C}$ & 81 & $120.37 \pm 12.95^{b}$ & $0.948 \pm 0.278^{b}$ \\
\hline \multicolumn{4}{|l|}{ Harvest in autumn } \\
\hline October & 54 & $57.68 \pm 5.68^{\mathrm{a}}$ & $0.400 \pm 0.172^{\mathrm{a}}$ \\
\hline November & 54 & $83.37 \pm 6.61^{b}$ & $0.213 \pm 0.121^{\mathrm{a}}$ \\
\hline December & 54 & $254.26 \pm 12.10^{\mathrm{c}}$ & $1.588 \pm 0.445^{b}$ \\
\hline \multicolumn{4}{|l|}{ Year } \\
\hline 2005 & 54 & $116.24 \pm 16.07^{\mathrm{a}}$ & $0.638 \pm 0.175^{\mathrm{a}}$ \\
\hline 2006 & 54 & $113.79 \pm 11.11^{\mathrm{a}}$ & $1.554 \pm 0.458^{b}$ \\
\hline 2007 & 54 & $165.29 \pm 15.49^{b}$ & $0.009 \pm 0.009^{c}$ \\
\hline
\end{tabular}

Mean values in the same column with different superscripts were significant at $P<0.05$

was higher in the over-mature forage from extensively used $1 \mathrm{C}$ stands than from the $2 \mathrm{C}$ stands. An apparent exception from the rule was the Arrhenatherum elatius stand in which the ergosterol content in forage was higher from the $2 \mathrm{C}$ stand than from the $1 \mathrm{C}$ stand in 
December. A similar finding was also recorded in the Dactylis glomerata forage in the second year of monitoring (Fig. 1). The intensity of use in summer season and the $\mathrm{S} \times \mathrm{C}$ interaction had effect on ergosterol content $(P<0.01)$. The ergosterol content increased between October and November. Between November and December, the forage ergosterol content increased even up to $254.26 \mathrm{mg} \cdot \mathrm{kg}^{-1}$. Variances were however observed among the species. Namely in the Festulolium forage, the ergosterol content was higher in October than in November. Harvest time in the autumn has a influence $(P<0.01)$ on the ergosterol content. The $\mathrm{S} \times \mathrm{A}$ and $\mathrm{C} \times \mathrm{A}$ interactions and the influence of the year was also significant $(P<0.01)$. The highest ergosterol content was recorded in the third year of study.

The content of zearalenone was highest in the Arrhenatherum elatius forage (Table 2). This high content of zearalenone in the Arrhenatherum elatius forage was contributed to namely by samples collected in December of the second studied year (Fig. 2). Effect of the species on the zearalenone content was significant $(P<0.01)$. Unlike in ergosterol, the content of zearalenone was higher in the forage from the $2 \mathrm{C}$ stands than in the forage from the $1 \mathrm{C}$ stands $(P<0.01)$. The higher ergosterol content in forage from younger growth was apparent particularly in the Arrheanatherum elatius forage in the second year of study. In contrast, in the Festulolium forage and in the first year of research, the zearalenone content was higher in the forage from the stand under more extensive use (1C). A conspicuous increase occurred in December $(P<0.01)$, up to $1.558 \mathrm{mg} \mathrm{kg}^{-1}$. The $\mathrm{S} \times \mathrm{C}$ and $\mathrm{S} \times \mathrm{A}$ interactions were significant $(P<0.01)$.

\section{Discussion}

The results show that the term of the last summer use (beginning of June or end of July) affects the ergosterol content in the autumn. If the period between the last summer harvest and the autumn harvest is short, the ergosterol content is lower. However, with the decreasing production, the forage quality is increasing (Opitz von Boberfeld and Banzhaf 2006). Decreasing ergosterol content with a shorter growing period indicates a slower development of fungi (Golinski et al. 2006). Older stands contain more senescent biomass of grasses. The population density of filamentous fungi is directly proportionate to the senescence process of plants (Behrendt et al. 2004).

The zearalenone content at the end of the growing season was higher in a shorter growing, which particularly shows in Arrhenatherum elatius in December. Golinski et al. (2006) arrived at similar conclusions for a grass stand in January. The higher zearalenone content may result from the increasing population of zearalenone-forming soil fungi. This, however, does not fully apply in Festulolium, in which the October zearalenone content was surprisingly higher in a phonologically older stand. According to D'Mello (2006), a zearalenone concentration ranging from $0.2-1.0 \mathrm{mg} \cdot \mathrm{kg}^{-1}$ is even toxic for rodents. Forage with a zearalenone content higher than $0.5 \mathrm{mg} \cdot \mathrm{kg}^{-1}$ is not advised for feeding (Mara sas et al. 1979). The highest occurrence of zearalenone was recorded in December in Arrhenatherum elatius, in which the limit of $0.5 \mathrm{mg} \cdot \mathrm{kg}^{-1}$ of zearalenone was exceeded $(P<0.05)$.

Comparing the contents of ergosterol and zearalenone in forage it is obvious that the high ergosterol content not always relates to the high content of zearalenone. This fact is corroborated also by Laser et al. (2003), who claim that the high content of ergosterol need not necessarily indicate a high content of mycotoxins. However, namely the Arrhenatherum elatius forage in the second year of monitoring exhibited in December not only higher ergosterol content but also clearly related higher zearalenone content. The second year of research was characterized by a very warm end of the growing season with the average monthly air temperature not falling below $0{ }^{\circ} \mathrm{C}$ from October to December. The warmer end of the growing season might have related also to the higher production of mycotoxins. On the other hand, at the end of the growing season in 2007, the detected 

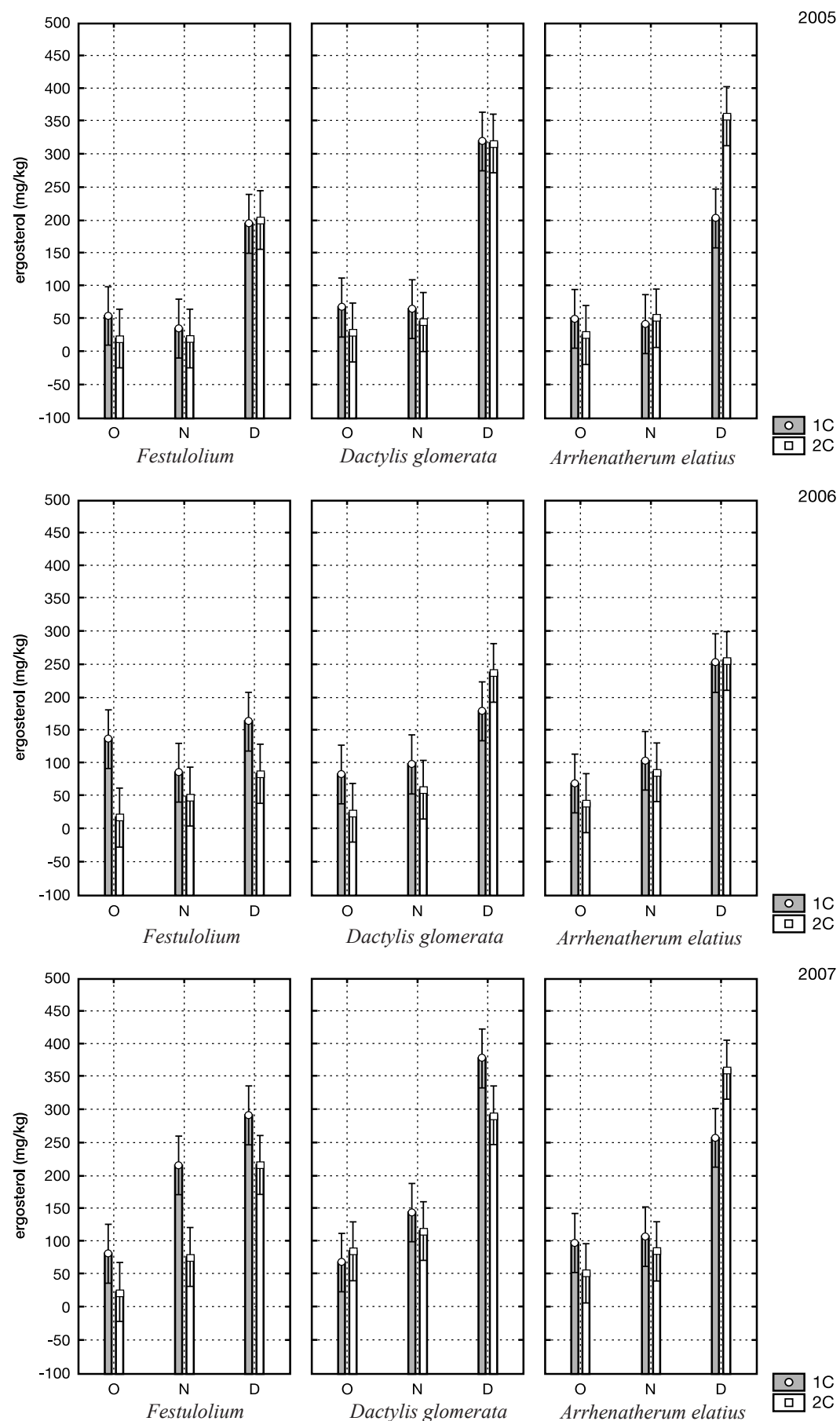

2007

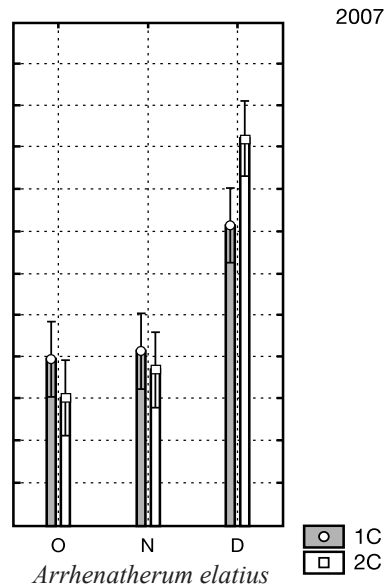

Fig. 1. The content of ergosterol $\left(\mathrm{mg} \cdot \mathrm{kg}^{-1}\right)$ in dependence on the species, intensity of use in summer and the term of use in the autumn in 2005-2007 

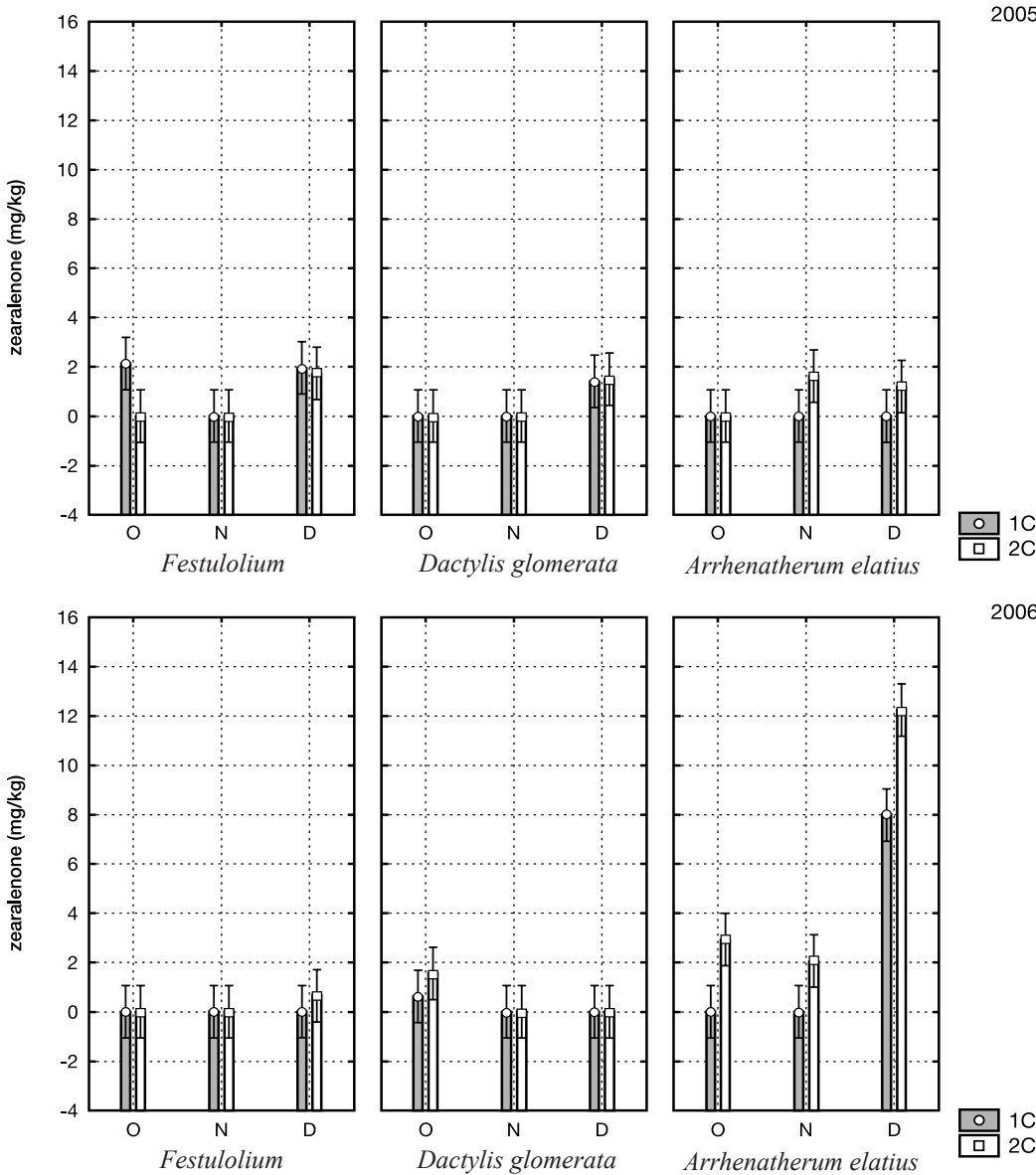

2006
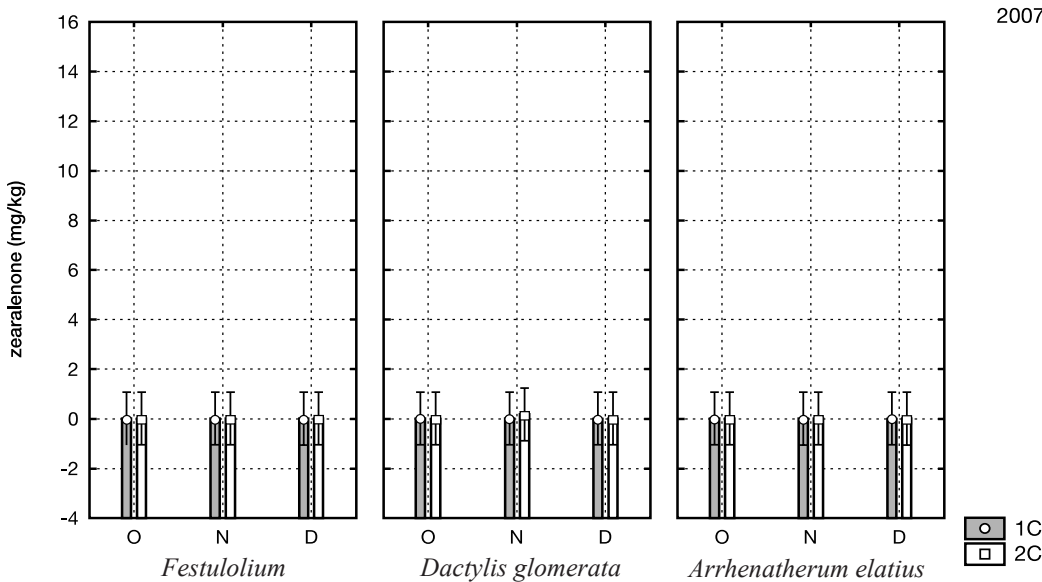

Fig. 2. The content of zearalenone $\left(\mathrm{mg} \cdot \mathrm{kg}^{-1}\right)$ in dependence on the species, intensity of use in summer and the term of use in the autumn in 2005-2007 
high content of ergosterol was combined with only a negligible occurrence of zearalenone in explored samples. The end of the growing season in 2007 was colder than the end of the growing season in 2006. The effect of not only biotic but also abiotic factors on the production of mycotoxins is mentioned by De Nijs et al. (1996), Engels and Krämer (1996), Behrendt et al. (2004), Golinski et al. (2006) point to a high ergosterol content in forage from a grass stand used in January and documents a high content of zearalenone occurring in connexion with the high ergosterol content in this month.

Ergosterol content was at the end of the growing season lowest in the Festulolium forage. In contrast, the highest ergosterol contents were found in the Dactylis glomerata and Arrhenatherum elatius forages. A higher safety of Festulolium was furthermore corroborated by the low zearalenone content. In contrast, the high ergosterol content in Arrhenatherum elatius was combined with high zearalenone content. The Dactylis glomerata forage - although exhibiting comparable ergosterol content as Arrhenatherum elatius at the end of the growing season - had low zearalenone content. The changes of ergosterol and zearalenone content were also apparent from October to December. The highest contents of studied secondary metabolites were diagnosed in December. A major share in the high zearalenone content in this month had namely the Arrhenatherum elatius forage. The ergosterol and zearalenone contents were also affected by the intensity of use in summer. The higher ergosterol content at the end of the growing season relates to the height of grass cover. In contrast, zearalenone was detected especially in phonologically younger stands that were in summer used for two cuts. The contents of ergosterol and zearalenone depended on the course of weather, too. While the production of ergosterol continued even at lower average monthly temperatures, the occurrence of zearalenone late in the autumn was stimulated particularly by higher temperatures. Higher content of ergosterol indicates a higher level of fungal infestation and hence a higher risk of mycotoxins occurring in the forage. However, the high content of ergosterol not always correlated with the high content of zearalenone.

When cattle is grazing in winter, a higher occurrence of mycotoxins in the feed may be expected and the related damage to animal metabolism may affect the number of diseased animals and/or diagnostics of animal diseases with consequent impact on animal production, performance and health and animal husbandry economics.

\section{Obsah sekundárních metabolitů u vybraných druhů trav na konci vegetačního období}

Cílem př́spěvku je posoudit prostřednictvím obsahu ergosterolu a zearalenonu bezpečnost píce Festulolium, Dactylis glomerata a Arrhenatherum elatius na konci vegetačního období. Vyhodnoceny byly také změny obsahu ergosterolu a zearalenonu v prủběhu podzimu a vliv intenzity využití v letním období na obsah sledovaných metabolitů. Sledované sekundární metabolity byly analyzovány prostřednictvím vysokorychlostní kapalinové chromatografie (HPLC). Obsah ergosterolu byl na konci vegetačního období nejnižší v píci Festulolium $\left(110,04 \mathrm{mg} \cdot \mathrm{kg}^{-1}\right)$. Naopak nejvyšší obsah ergosterolu byl zaznamenán v píci Dactylis glomerata $\left(145,73 \mathrm{mg} \cdot \mathrm{kg}^{-1}\right)$ a Arrhenatherum elatius $\left(139,55 \cdot \mathrm{mg} \mathrm{kg}^{-1}\right)$. Bezpečnost Festulolium potvrdil také nízký obsah zearalenonu $\left(0,357 \mathrm{mg} \cdot \mathrm{kg}^{-1}\right)$. Naopak vysoký obsah ergosterolu u Arrhenatherum elatius doplňuje také vysoký obsah zearalenonu (1,554 $\left.\mathrm{mg} \cdot \mathrm{kg}^{-1}\right)$. Píce Dactylis glomerata vykazuje koncem vegetačního období sice srovnatelný obsah ergosterolu jako píce Arrhenatherum elatius, ale obsah zearalenonu je zde srovnatelný s Festulolium. Mezi sledovanými druhy byl statisticky průkazný rozdíl $(P<0,01)$ v obsahu ergosterolu a zearalenonu. Změny obsahu ergosterolu a zearalenonu byly patrné také od ř́jna do prosince. Průkazně $(P<0,01)$ nejvyšší obsah ergosterolu byl diagnostikován v prosinci $\left(254,26 \mathrm{mg} \cdot \mathrm{kg}^{-1}\right)$. Na vyšším $(P<0,01)$ obsahu zearalenonu v tomto měsíci $\left(1,588 \mathrm{mg} \cdot \mathrm{kg}^{-1}\right)$ se podílela zejména píce Arrhenatherum elatius. Na obsah ergosterolu 
a zearalenonu koncem vegetačního období měl vliv také počet sečí v letním období $(P<0,01)$. Vyšší obsah ergosterolu indikoval vyšší úroveň fungálního napadení píce a s tím související riziko výskytu mykotoxinů. Vysoký obsah ergosterolu však nekoreluje vždy s vysokým obsahem zearalenonu.

\section{Acknowledgements}

The work was financially supported by Grant PD 521/06/P253 "Structure, quality and hygiene of grass biomass at the end of the vegetation period", funded by the Grant Agency of the Czech Republic. The research was also aided by the Research plan No. MSM6215648905 "Biological and technological aspects of sustainability of controlled ecosystems and their adaptability to climate change", financed by the Ministry of Education, Youth and Sports of the Czech Republic.

\section{References}

Behrendt U, Müller T, Seyfarth W 1997: The influence of extensification in grassland management on the populations of micro-organisms in the phyllosphere of grasses. Microbiol Res 152: 75-85

Behrendt U, Stauber T, Müller T 2004: Microbial communities in the phyllosphere of grasses on fenland at different intensities of management. Grass Forage Sci 59: 169-179

De Nijs M, Soentoro P, Delfgou-Van Asch E, Kamphuis H, Rombouts FM, Notermans SHW 1996: Fungal infection and presence of deoxynivalenol and zearalenone in The Netherlands. J Food Protect 59: 772-777

D’Mello JPF 2003: Food safety contaminants and toxins. CABI Publishing, Wallingford, 452 p.

Dohnal V, Kaderová I, Ježková A, Skládanka J 2007: Ergosterol content in selected grasses on the end of vegetation period. Acta Univ Agric Silvic Mendel Brun 55: 9-14

Engels R, Krämer J 1996: Incidence of fusaria and occurrence of selected Fusarium mycotoxins on Lolium ssp. in Germany. Mycotoxin Res 12: 31-40

Giesler LJ, Yuen GY, Horst GL 1996: The microclimate in tall fescue turf as affected by canopy density and its influence on brown patch disease. Plant Dis 80: 389-394

Golinski P, Opitz von Boberfeld W, Kostecki M, Kaczmarek Z, Golinski PK 2006: Accumulation of secondary metabolities formed by field fungi in autumn-saved herbage. J Agron Crop Sci 192: 344-351

Laser H, Opitz von Boberfeld W, Wöhler K, Wolf D 2003: Effect of the botanical composition and weather conditions on mycotoxins in winter forage from grassland. Mycotoxin Res 19: 87-90

Marasas WFO, Van Rensburg SJ, Mirocha CJ 1979: Incidence of fusarium species and the mycotoxins, deoxynivalenol and zearalenone, in corn produced in esophageal cancer areas in Transkei. J Agric Food Chem 27: 1108-1112

Marín S, Vinaixa M, Brezmes J, Llobet E, Vilanova X, Correig X, Ramos AJ, Sanchis V 2007: Use of a MSelectronic nose for prediction of early fungal spoilage of bakery products. Int J Food Microbiol 114: 10-16

Opitz von Boberfeld W 1996: Changes of the quality including mycotoxin problems of the primary growth of a hay meadow - Arrhenatherion elatioris. Agribiol Res 49: 52-62

Opitz von Boberfeld W, Theobald PC, Laser H 2003: Prediction of digestibility and energy concentration of winter pasture forage and herbage of low-input grassland - a comparison of method. Arch Anim Nutr 57: $167-176$

Opitz von Boberfeld W, Banzhaf K 2006: Yield and forage quality of different x Festulolium cultivars in winter. J Agron Crop Sci 192: 239-247

Opitz von Boberfeld W, Banzhaf K, Hrabě F, Skládanka J, Kozlowski S, Golinsky P, Szeman L, Tasi J 2006: Effect of different agronomical measures on yield and quality of autumn saved herbage during winter grazing $2^{\text {nd }}$ communication: crude protein, energy and ergosterol concentration. Czech J Anim Sci 51: 271-277

Prigge EC, Bryan WB, Goldman-Innis ES 1999: Early and late season grazing of orchardgrass and fescue hayfields overseeded with red clover. Agron J 91: 690-696

Wolf D 2002: On the effect of stand, pre-utilization and date of winter harvest on quality and yield of winter pasture. PhD. Thesis. Justus Liebig University, Giessen, 127 p. 